\section{Growth and Yield of Tomato on Plastic Film Mulches as Affected byTomato Spotted Wilt Virus}

\author{
Juan C. Díaz-Pérez ${ }^{1}$ K. Dean Batal², Darbie Granberry ${ }^{3}$, \\ Denne Bertrand ${ }^{4}$, and David Giddings ${ }^{4}$ \\ Department of Horticulture, Coastal Plain Experiment Station-Tifton \\ Campus, University of Georgia, Tifton, GA 31793
}

\author{
Hanu Pappu ${ }^{5}$ \\ Department of Plant Pathology, Coastal Plain Experiment Station-Tifton \\ Campus, University of Georgia, Tifton, GA 31793
}

Additional index words. Lycopersicon esculentum, thrips, TSWV, viral disease, tospovirus, Bunyanviridae

\begin{abstract}
Tomato spotted wilt virus (TSWV) is a serious constraint to tomato production worldwide. Losses are significant because the disease is difficult to control and most of the commercially available tomato cultivars are susceptible to TSWV. This study was intended to provide information that could be used to design more appropriate disease management strategies. The objective was to determine the relationship of tomato plant growth and fruit yield with the time of TSWV symptom appearance. Experiments were carried out during Spring 1999 and 2000, using drip irrigation and plastic film mulched beds with black plastic mulch alone (1999) or different colored mulches (2000). The mulches used were black, black-on-silver, gray-on-black, red, silver-on-black, silver (painted) and white-on-black, and bare soil. The 1999 experiment included a single TSWV-susceptible cultivar (Florida-47), while the 2000-experiment included two TSWV-susceptible (Florida-91 and Sun Chaser) and one TSWV-resistant cultivars (BHN-444). Colored mulches and tomato cultivars affected the time between transplanting and appearance of first symptoms of TSWV. For all tomato cultivars, vegetative top fresh weight $(\mathrm{FW})$, fruit number and total fruit yield increased linearly with the time the plants remained free from TSWV symptoms. Marketable fruit yield also increased as the time from transplanting to the first appearance of symptoms increased. When data for cultivars were pooled, vegetative top FW and total fruit yield were reduced by $2.1 \%$ and $2.3 \%$, respectively, for each day prior to harvesting that plants showed TSWV symptoms.
\end{abstract}

Tomato spotted wilt disease has a worldwide distribution. This disease can cause serious damage to field-grown tomato and pepper in Australia, Argentina, Canada, Spain and the United States (Hawaii and southeast U.S.) (Francki and Hatta, 1981; Olson et al., 2000; Roselló et al., 1996; Zitter, 1997). An-

Received for publication 30 Nov. 2001. Accepted for publication 18 July 2002 . We are graciously thankful to B. Mullinix Jr. for statistical assistance, and to P. Bertrand, M. Hall, and B. Mandal for reviewing the manuscript. Thanks also to E. Folds for secretaria support and to G. Acuña for help with field and laboratory tasks. We acknowledge support of the following donors: Asgrow, BHN, and Peto Seed for tomato seeds; United Irrigation and Roberts Irrigation Products, for drip tape; Hydro Agri North America, for calcium nitrate liquid fertilizer; and Green-Tek and Sonoco for plastic film mulches. Mention of trade names in this publication does not imply endorsement by the Univ. of Georgia of products named, nor criticism of similar ones not mentioned.

${ }^{1}$ Assistant Professor. To whom reprint requests should be addressed.E-mail: jcdiaz@tifton.uga.edu

${ }^{2}$ Associate Professor.

${ }^{3}$ Professor.

${ }^{4}$ Research Technician III.

${ }^{5}$ Assistant Professor. Present address: USDA-APHIS 4700 River Road, Unit 133, Riverdale, MD 20737. nual losses due to spotted wilt in tomato, pepper, peanut and tobacco exceed $\$ 100$ million in the state of Georgia alone (Woodward, 2001). Tomato spotted wilt has one of the widest host ranges of any virus and is incited by tomato spotted wilt virus (TSWV), of genus Tospovirus, family Bunyaviridae (Sherwood et al., 2000). Worldwide, TSWV is known to be transmitted by nine species of thrips (Thripidae: Thysanopterae) (Zitter, 1997), of which Frankliniella occidentallis Pergande is the predominant vector in Europe (Ananthakrishnan, 1980), south Georgia (Riley and Pappu, 2000), north Florida (Salguero-Navas et al., 1991) and Alabama (Brown, 1989). The virus is difficult to eliminate because it has a wide host range that comprises several crops and numerous weeds (Francki and Hatta, 1981; Roselló et al., 1996).

In tomatoes and peppers, losses are significant because the majority of currently available cultivars are susceptible to TSWV. The use of pesticides to control thrips is usually ineffective for management of TSWV (Brown, 1989; Cho et al., 1998; Helyer and Brobyn, 1992), although imidacloprid applications to tomato transplants may offer some protection (Riley and Pappu, 2000). As a complement to chemical control, cultural control measures such as the use of silver reflective mulches may be considered as part of a TSWV management strategy (Brown et al., 1989; Olson et al., 2000; Schalk and Robbins, 1987). Plastic film mulches have also been found to reduce the populations of thrips and other insect vectors (Csizinszky et al., 1995; Farias-Larios and Orozco-Santos, 1997; Olson et al., 2000).

Plants infected in early stages of development will show severe TSWV symptoms and may eventually die (Francki and Hatta, 1981; Gitaitis et al., 1998). However, it is unclear how TSWV affects plant growth and yield as plants advance in their development. The objective of this study was to determine the relationship of the time when TSWV symptoms first appeared on the subsequent vegetative top growth and fruit yield of tomato plants.

\section{Materials and Methods}

Crop growing conditions and experimental design. This study was conducted at the Horticulture Farm, UGACoastal aPlain Experiment Station, Tifton, Ga., during Spring 1999 and 2000. In 1999, $\approx 300$ 'Florida-47'tomato plants were transplanted into eight $24-\mathrm{m}$-long beds, 0.9 -m wide beds formed on 1.8 -m centers, and mechanically covered with $38-\mu$ m-thick black plastic mulch. The soil was fertilized with N,P, and $\mathrm{K}$ at 60,101 and $108 \mathrm{~kg} \cdot \mathrm{ha}^{-1}$, respectively before mulches were applied. The soil was fumigated with a mixture of 3 methyl bromide : 1 chloropicrin (by weight) at $224 \mathrm{~kg} \cdot \mathrm{ha}^{-1}$ on 10 Mar. 1999. Drip irrigation tape (T-Tape; T-Systems Intl., San Diego, Calif.), with 30.5$\mathrm{cm}$ emitter spacing, $8 \mathrm{~mL}$ per minute emitter flow at $5631 \mathrm{~kg} \cdot \mathrm{m}^{2}(8 \mathrm{lb} /$ inch $)$ pressure, and $0.15 \mathrm{~mm}$ wall thickness was placed 3 -cm-deep in the center of the bed. The plastic mulch, drip tape and fumigant were applied simultaneously with a tractor. Six-week-old tomato transplants were set $0.6 \mathrm{~m}$ apart in a single row per bed. Planting was on 31 Mar. 1999. After transplanting, $250 \mathrm{~mL}$ of starter fertilizer solution was manually applied directly to the base of each transplant. The starter solution consisted of $530 \mathrm{~mL}$ of $10-34-00$ fertilizer mixed in $100 \mathrm{~L}$ of water. Three weeks after transplanting, plants were fertigated weekly for 9 weeks with $\mathrm{N}$ and $\mathrm{K}$ totaling 110 and 62 $\mathrm{kg} \cdot \mathrm{ha}^{-1}$, respectively. The actual fertigation rate for $\mathrm{N}$ and $\mathrm{K}$ was 1.4 and $0.8 \mathrm{~kg} \cdot \mathrm{ha}^{-1}$ per day at early stages, 2.0 and $1.1 \mathrm{~kg} \cdot \mathrm{ha}^{-1}$ per day during fruit development, and 1.4 and $0.8 \mathrm{~kg} \cdot \mathrm{ha}^{-1}$ per day at late stages of development.

In 2000, two TSWV-susceptible [Florida-91 (Asgrow, Tifton, Ga.) and Sun Chaser (Petoseed, Saticoy, Calif.)] and one TSWV-resistant cultivars [BHN-444 (BHN Research, Bonita Springs, Fla.)] were planted on seven colored mulches and bare soil. The mulches used were $38-\mu$ m thick black, dull gray-on-black (Leco, Montreal, Canada), black mulch painted with dull silver paint ["silver-painted" (QPL-T-359, Sentry Paint, Darby, Pa.)], white-on-black (Leco), red (Sonoco), 25- $\mu$ m-thick black-onsilver (Sonoco Products Co., Hartsville, S.C.), and black-on-silver as above but inverted with dull silver side up ("silver-on-black"). The design was a randomized complete block with 
three replications and a split-plot arrangement, with main plot being mulch $(n=8)$ and the subplot being cultivar $(n=3)$. Before laying the mulches, the soil was fertilized with N, P, and $\mathrm{K}$ at 90,90 , and $90 \mathrm{~kg} \cdot \mathrm{ha}^{-1}$, respectively. The soil was fumigated (broadcast) with a mixture of 3 methyl bromide : 1 chloropicrin (by weight) at $448 \mathrm{~kg} \cdot \mathrm{ha}^{-1}$ on $21 \mathrm{Feb} .2000$. The plastic mulch and drip tape were applied simultaneously with a tractor on 14 Mar. 2000. Drip tape specifications and installation were as in 1999. Six-week-old tomato transplants were set $0.6 \mathrm{~m}$ apart in a single row per bed on 5 Apr. 2000. The sub-plot consisted of 16 plants, with 10 plants being the useful plot and six plants being used as borders.

Three weeks after transplanting, and then weekly for 7 weeks, plants were fertilized with $\mathrm{N}$ and $\mathrm{K}$ totaling each $93 \mathrm{~kg} \cdot \mathrm{ha}^{-1}$. The actual rate for $\mathrm{N}$ and $\mathrm{K}$ was $1.6 \mathrm{~kg} \cdot \mathrm{ha}^{-1}$ per day at early stages, $2.2 \mathrm{~kg} \cdot \mathrm{ha}^{-1}$ per day during fruit development, and $1.7 \mathrm{~kg} \cdot \mathrm{ha}^{-1}$ per day at late stages of development. Insect and disease control was done according to the recommendations of the Georgia Extension Service (Guillebeau, 2001).

Quantification of symptomatic plants. Evaluation of tomato spotted wilt disease was carried out based on natural (thrips-borne) infection. Individual plants were monitored visually for TSWV symptoms every 4-7 d for the entire season and the time (day after transplanting, DAT) each plant first exhibited TSWV symptoms was recorded. The presence of TSWV in symptomatic plants was confirmed by enzyme-linked immunosorbent assay (ELISA), using a commercially available kit (Agdia, Elkhart, Ind.). Incidence was expressed as the percent of symptomatic plants per cultivar and mulch combination. Incidence data were arcsin transformed prior to statistical analysis. After statistical analysis, incidence data were transformed back to percent. Asymptomatic plants were not subjected to ELISA.

Vegetative top fresh weight and fruit yield. Tomato plants (tops) were excised at the soil level on 9 June 1999 (70 DAT) and on 16 June 2000 (72 DAT). Vegetative top fresh weight (FW), number of fruit, and total fruit FW of individual tops were determined. In 1999, fruit were graded according to [U.S. Dept. of Agriculture (USDA)] standards and the fruit number and weight in each grade category were determined. In 2000, fruit were not graded. Fruit yield was measured as total fruit (both green and red) FW per individual plant.

Statistical analysis. Analysis of the data was done with SAS, using the Mixed Procedure (SAS Institute, 2000). For each individual plant, the relationship of final vegetative top FW and fruit yield with the time (days after transplanting) when the first TSWV symptoms appeared, were analyzed through regression.

\section{Results}

Dynamics of TSWV symptoms appearance and TSWV incidence. In 1999, the cumula- tive number of plants showing symptoms of TSWV increased in a sigmoidal fashion, with the first plants exhibiting TSWV symptoms at 28 DAT and $100 \%$ of plants had symptoms at harvest (70 DAT). In 2000, the first symptoms were detected 22 DAT, with $2.3 \%$ of symptomatic plants in 'Sun Chaser', $1.8 \%$ in 'Florida-91' and $0.3 \%$ in 'BHN-444'. The first symptomatic plants were found 22 DAT across all mulches, except on gray and silver mulches. As an average, appearance of first TSWV symptoms were delayed on gray mulch, followed by black-on-silver, silver-on-black and silver-painted (Table 1). 'Florida-91' and 'Sun Chaser' showed first symptoms of TSWV 3-4 dearlier than 'BHN444' (Table 1). The number of symptomatic plants increased until harvest and termination of the experiment. Among mulches, TSWV incidence was highest for plants grown on white mulch, with incidences on the other mulches and bare soil ranging from $14 \%$ to $35 \%$ (Table 1). Among cultivars, 'BHN-444' had the lowest incidence of TSWV (12\%), while 'Florida-91' and 'Sun Chaser' had incidences that were about three times greater (Table 1).

Relationship of time of TSWV symptom expression with vegetative top $F W$ and total fruit $F W$. Vegetative top FW (Fig. 1), total fruit FW (Fig. 2), total fruit number, and the number and weights of fruit at all grade categories increased linearly (i.e., slope values were positive, Table 2) with increasing time after transplanting the plants remained free from TSWV symptoms. There was a high incidence of blossom-end-rot (BER) in both years, across all cultivars and mulches, which was probably associated with presence of high-temperature conditions $\left(>38^{\circ} \mathrm{C}\right)$ and fluctuations in soil moisture. At the end of the season, residual soil calcium levels were high. The number of fruit with BER was not related with the time of appearance of TSWV symptoms.

Relative vegetative top $F W$ and total fruit $F W$. Final vegetative top $\mathrm{FW}$ and total fruit FW differed among cultivars (Table 1). Thus, in order to compare data from the two experiments, vegetative top FW and total fruit FW values of individual plants were expressed as "relative vegetative top $F W$ " and "relative fruit $F W$." Relative values were calculated by dividing the value of each symptomatic individual plant over the mean value of symptomless plants in the test (1999) or in each mulch/cultivar combination (2000). It was assumed that these relative values measure the impact of TSWV on the potential plant FW and total fruit FW for each mulch/cultivar combination, under those specific conditions. Pooled data for the four cultivars indicated that both, relative vegetative top FW and relative fruit FW were linearly related with the time when TSWV symptoms were first detected (Fig. 3). From the relationships of Fig. 3, values of potential vegetative top $\mathrm{FW}$ and total fruit $\mathrm{FW}$ (i.e., relative values $=100 \%$ ) occurred in plants that remained free from TSWV symptoms. For each day before harvest that individual plants showed first symptoms of TSWV, vegetative top FW decreased by $2.1 \%$ and total fruit FW by $2.3 \%$ relative to their potential.

Effect of mulches and cultivars on vegetative top $F W$ and total fruit $F W$. Based on one year of data, tomatoes grown on silver-painted mulch produced the heaviest plants, while those plants grown on white mulch were among the lightest (Table 1). Total fruit FW was among the highest for plants on gray mulch and lowest on white mulch and bare soil. Mean vegetative top FW was similar among cultivars. Total fruit FW was highest for 'BHN-444' and lowest for 'Florida-91'. The 2000-experiment was terminated after a

Table 1. Effects of plastic mulch and cultivar on the days after transplanting (DAT) when the first symptoms of tomato spotted wilt virus (TSWV) were detected, incidence of TSWV, final vegetative top fresh weight (FW) and total fruit FW in tomato grown in Spring 2000.

\begin{tabular}{|c|c|c|c|c|}
\hline Treatment & $\begin{array}{l}\text { Time } \\
\text { (DAT) }\end{array}$ & $\begin{array}{c}\text { Incidence }^{\mathrm{z}} \\
(\%)\end{array}$ & $\begin{array}{c}\text { Vegetative top FWy } \\
(\mathrm{kg} / \mathrm{plant})\end{array}$ & $\begin{array}{l}\text { Fruit FW } \\
\text { (kg/plant) }\end{array}$ \\
\hline \multicolumn{5}{|c|}{ Plastic mulch } \\
\hline Bare soil & $45 b^{2}$ & $16 \mathrm{c}$ & $1.35 \mathrm{bc}$ & $1.56 \mathrm{c}$ \\
\hline Black & $45 \mathrm{~b}$ & $35 \mathrm{~b}$ & $1.38 \mathrm{bc}$ & $2.46 \mathrm{ab}$ \\
\hline Black-on-silver & $49 \mathrm{ab}$ & $28 \mathrm{bc}$ & $1.26 \mathrm{bc}$ & $2.36 \mathrm{~b}$ \\
\hline Gray & $52 \mathrm{a}$ & $26 \mathrm{bc}$ & $1.39 \mathrm{~b}$ & $2.84 \mathrm{a}$ \\
\hline Red & $46 \mathrm{~b}$ & $23 \mathrm{bc}$ & $1.23 \mathrm{bc}$ & $2.64 \mathrm{ab}$ \\
\hline Silver-on-black & $49 \mathrm{ab}$ & $33 \mathrm{~b}$ & $1.41 \mathrm{~b}$ & $2.46 \mathrm{ab}$ \\
\hline Silver- painted & $47 \mathrm{ab}$ & $14 \mathrm{c}$ & $1.74 \mathrm{a}$ & $2.31 \mathrm{~b}$ \\
\hline White & $44 \mathrm{~b}$ & $70 \mathrm{a}$ & $1.19 \mathrm{c}$ & $1.36 \mathrm{c}$ \\
\hline \multicolumn{5}{|c|}{ Cultivar } \\
\hline Florida-91 & $45 \mathrm{~b}$ & $38 \mathrm{a}$ & $1.40 \mathrm{a}$ & $1.80 \mathrm{c}$ \\
\hline BHN-444 & $49 \mathrm{a}$ & $12 \mathrm{~b}$ & $1.37 \mathrm{a}$ & $2.79 \mathrm{a}$ \\
\hline Sun Chaser & $46 \mathrm{~b}$ & $42 \mathrm{a}$ & $1.34 \mathrm{a}$ & $2.15 \mathrm{~b}$ \\
\hline \multicolumn{5}{|c|}{$P$ values from $A N O V A$} \\
\hline Plastic mulch & 0.013 & 0.011 & 0.0001 & 0.0001 \\
\hline Cultivar & 0.006 & 0.002 & 0.638 & 0.0001 \\
\hline Interaction & 0.960 & 0.452 & 0.341 & 0.201 \\
\hline
\end{tabular}

${ }^{z}$ Mean of symptomatic plants only.

${ }^{y}$ Mean of symptomatic and asymptomatic plants, calculated from individual plant data.

${ }^{2}$ Mean separation within columns by LSD $P \leq 0.05$. 

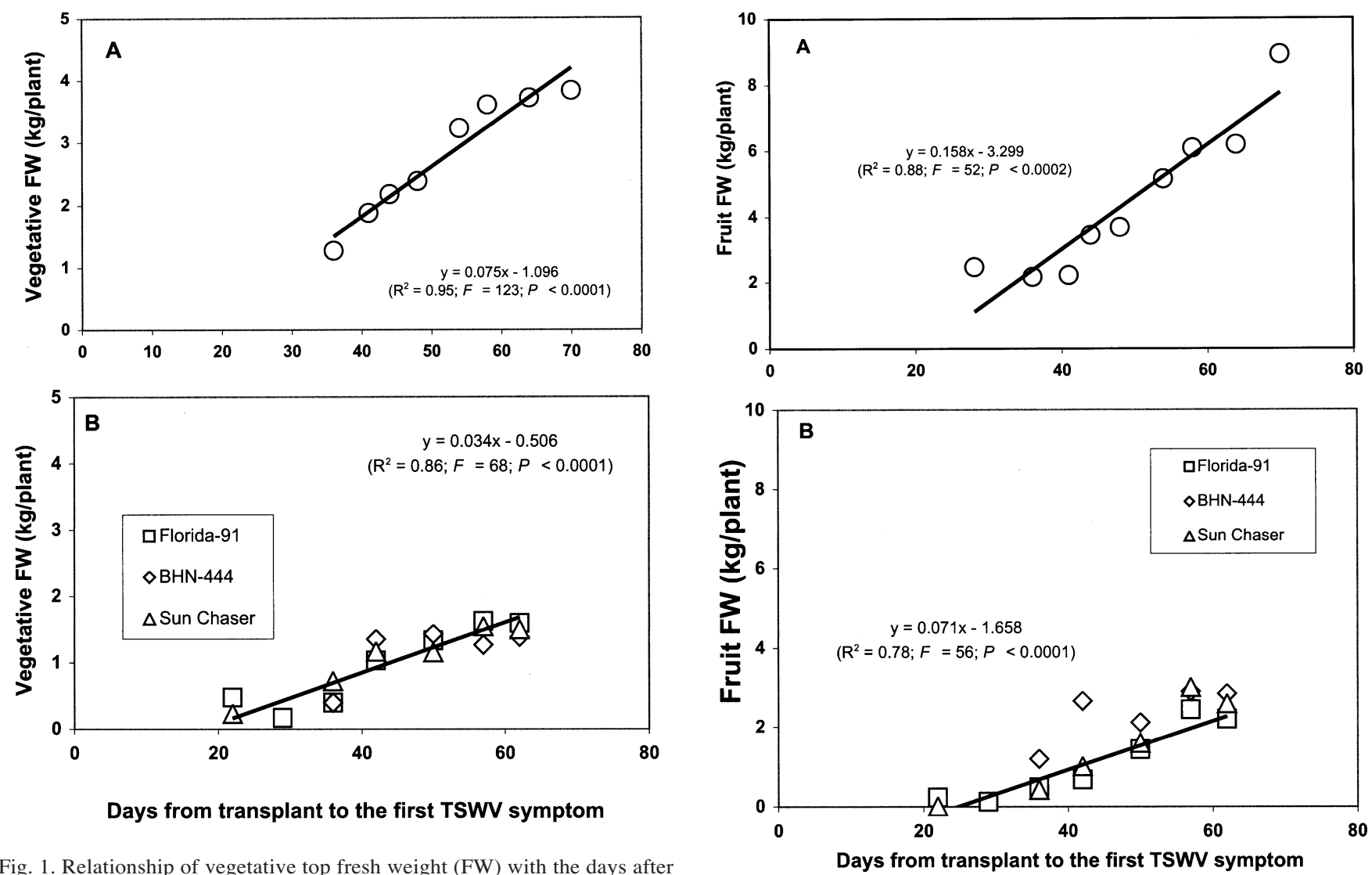

Fig. 1. Relationship of vegetative top fresh weight (FW) with the days after transplanting (DAT) when tomato plants first expressed symptoms of tomato spotted wilt virus. Symbols represent the mean of plants expressing symptoms on the same day. (A) Solid line represents the linear regression for 'Florida-47' (Spring 1999). (B) Solid line represents the linear regression for the pooled data for 'Florida-91', 'BHN-444', and 'Sun Chaser' (Spring 2000).

Fig. 2. Relationship of total fruit fresh weight (FW) with the number of days after transplanting (DAT) when plants first expressed symptoms of tomato spotted wilt virus. Symbols represent the mean of plants expressing symptoms on the same day. (A) Solid line represents the linear regression for 'Florida-47' (Spring 1999). (B) Solid line represents the linear regression for the pooled data for 'Florida-91', 'BHN-444', and 'Sun Chaser' (Spring 2000).

single harvest because there was a high incidence of whiteflies, blossom-end rot, and fruit cracking. Thus, only total fruit yields are presented.

\section{Discussion}

Successful tomato production is normally associated with healthy vegetative top growth throughout the growing season. Results of this study revealed that tomato spotted wilt disease seriously disrupts normal plant growth. There was an increasing reduction of vegetative top FW, fruit number and fruit yield (total and marketable) with increasingly earlier expression of TSWV symptoms during tomato plant development. Early plant infection with TSWV typically results in severe symptoms or plant death (Francki and Hatta, 1981; Gitaitis et al., 1998; Moriones et al., 1998). The mechanisms through which TSWV affects tomato plant growth and yield are not fully understood. However, TSWV infections in tobacco have been associated with reductions in leaf chlorophyll content and diminished rates of $\mathrm{CO}_{2}$ assimilation (Goodman et al., 1986). Wilting associated with TSWV is probably an indication of plant water deficits, which may also affect gas exchange and shoot growth.

Total fruit FW and marketable yield of tomato plants were reduced to some extent, even when plants showed symptoms late in plant development. Previous reports show that early disease causes the most damage to the plant, and that the amount of injury caused by TSWV is difficult to predict (Padgett et al., 1995). Tomato fruit weights are reduced in tomato plants infected early in the season (Gitaitis et al., 1998; Moriones et al., 1998). Tomato plant age also affects the transmission of TSWV (Chaisuekul, 2001). Our results show that, compared to symptomless plants, total fruit FW of symptomatic plants was reduced by $2.3 \%$, for each day before harvest that plants first exhibited symptoms of TSWV. This $2.3 \%$ /day reduction is similar to the $2 \%$ /day reduction calculated from the data of Gitaitis et al. (1998). Thus, delay of TSWV symptoms is associated with an increase in tomato yield.

Integrated management is probably the most effective method to manage TSWV and delay the expression of symptoms (Cho et al., 1998). Plants grown on silver mulches have fewer thrips compared to plants grown on other mulches (Csizinsky et al., 1995; Olson et al., 2000). Plants on bare soil typically have higher incidences of TSWV. However, in this study, plants on bare soil showed a reduced TSWV incidence, probably because they escaped infection due to their delayed development. During the spring in southern Georgia, late tomato plantings have lower thrips levels than early tomato plantings (Riley and Pappu, 2000). In a 5-year study in Florida under commercial conditions, tomato plants grown on silver reflective mulch had lower thrips numbers and TSWV incidence compared to plants grown on black plastic mulch (Olson et al., 2000). Similarly, Riley and Pappu (2000) found that silver reflective mulch in combination with intensive insecticide applications and resistant cultivars resulted in reduced thrips populations and TSWV incidence. Reduction in thrips population has been attributed to the mulch color effect on the vector, due to a modification of the light environment around the plant (Csizinszky et al., 1995; Olson et al., 2000). However, appearance of TSWV symptoms depends on factors other than the number of thrips. In addition to light effects on the vector, colored mulches modify root zone temperature (RZT) under the mulch. RZT directly affects tomato plant growth (DíazPérez and Batal, 2002), which may influence plant response to TSWV. Results of a one-year test indicate that symptoms of TSWV were delayed in plants grown on gray, silver-onblack, black-on-silver, and silver-painted mulches (Table 1), where the mean RZT for the season approached the optimal RZT $\left(26.1^{\circ} \mathrm{C}\right)$ for tomato plant growth and yield. These results suggest that RZT, as modified by plastic mulches, may be related to the 
Table 2. Regression parameters for the relationships of the time (days after transplanting) when the first symptoms of tomato spotted wilt virus were detected with vegetative top fresh weight (FW), fruit FW and number of fruit at all grade categories in individual plants of 'Florida-47' tomato grown in Spring $1999(\mathrm{n}=214)$.

\begin{tabular}{lccc}
\hline Plant attribute & Intercept & Slope & $R^{2}$ \\
\hline Vegetative top FW (kg/plant) & -1.47 & 0.083 & $0.602^{* *}$ \\
& Fruit FW (kg/plant) & & \\
Total & -7.92 & 0.252 & $0.657^{* *}$ \\
Marketable & -2.59 & 0.076 & $0.484^{* *}$ \\
Large & -1.52 & 0.039 & $0.416^{* *}$ \\
Medium & -0.68 & 0.019 & $0.274^{* *}$ \\
Small & -0.34 & 0.016 & $0.225^{* *}$ \\
Culls & -5.33 & 0.177 & $0.610^{* *}$ \\
& Number of fruit per plant & \\
Total & -90.76 & 2.804 & $0.629^{* *}$ \\
Marketable & -16.97 & 0.534 & $0.474^{* *}$ \\
Large & -8.26 & 0.217 & $0.407^{* *}$ \\
Medium & -5.29 & 0.151 & $0.264^{* *}$ \\
Small & -3.25 & 0.161 & $0.205^{* *}$ \\
Culls & -73.79 & 2.444 & $0.628^{* *}$ \\
Fruit with blossom-end rot & 1.3 & 0.034 & $0.01^{\text {Ns }}$ \\
\hline Ns, ** Nonsignificant or significant at $1 \%$ level, respectively. &
\end{tabular}
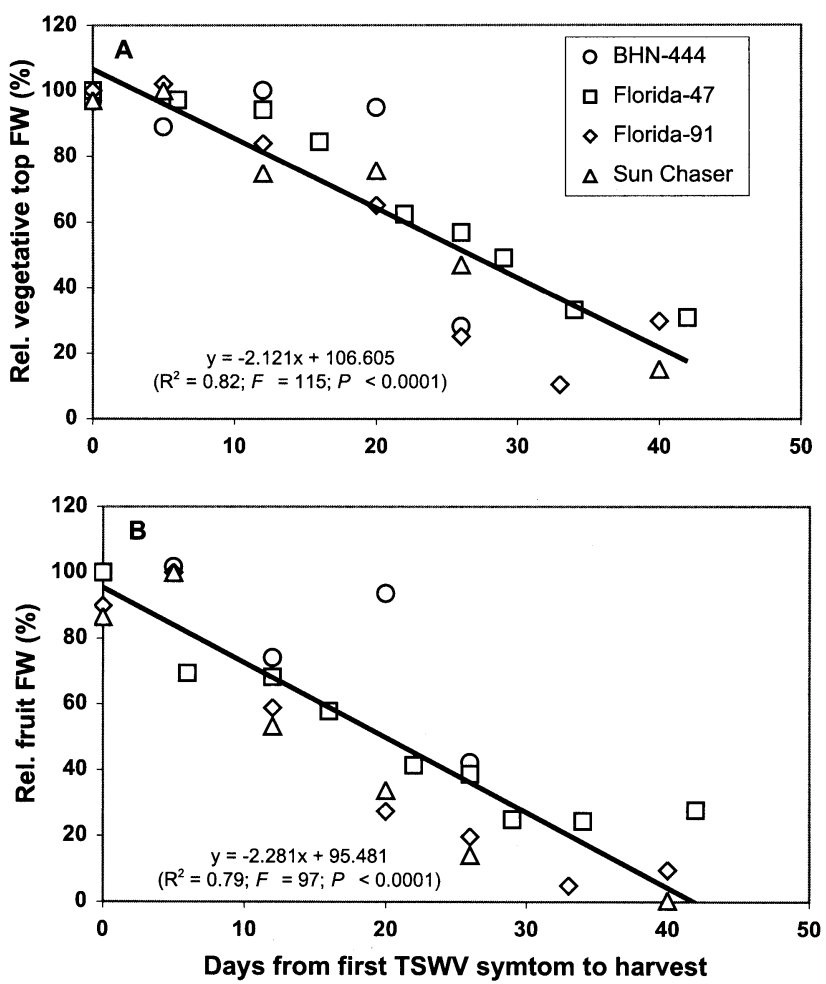

Fig. 3. Relative vegetative top fresh weight (FW) and fruit FW of plants with symptoms of tomato spotted wilt virus (TSWV), as a function of the time from first symptom appearance to harvest. Plants were harvested only once. It was assumed that plants reached their potential vegetative top FW and fruit yield (relative value $=100 \%$ ) when no symptoms of TSWV were present. The solid lines represent the linear regressions for $(\mathbf{A})$ relative vegetative top $\mathrm{FW}$ and $(\mathbf{B})$ relative total fruit $\mathrm{FW}$. Linear regressions were calculated from pooled data for tomato cultivars grown on black plastic mulch in 1999 and on colored mulches in 2000 .

appearance of TSWV symptoms. However, environmental factors other than RZT may also influence the impact of TSWV on tomato plants, as suggested by the study of Diez et al. (1999) who found that growth and yield of tomato plants grown under mesh were higher compared to plants grown in open air conditions.

In conclusion, vegetative top FW and total fruit yield were reduced by $2.1 \%$ and $2.3 \%$ relative to symptomless plants, for each day prior to harvesting that plants showed TSWV symptoms. Thus, in order to obtain high tomato yields, appearance of TSWV symptoms should be delayed as much as possible during the entire season, but particularly during early stages of plant development. Use of TSWVresistant cultivars and utilization of colored mulches may be useful in the management of TSWV.
Literature Cited

Ananthakrishnan, T.N. 1980. Thrips, p. 149-164. In: K.F. Harris and K. Maramorosch (eds.). Vectors of plant pathogens. Academic, New York.

Brown. S.L., J.E. Brown, and M.C. Osborn. 1989. The influence of plastic mulch color on thrips populations on tomato. Proc. Natl. Agr. Plastics Cong. 21:198-201.

Chaisuekul, C. 2001. Tomato plant age effects on the transmission of Tomato spotted wilt virus and insecticide inhibition of the thrips-vector feeding. MS Thesis, Dept. of Entomology, Univ. of Georgia, Athens.

Cho, J., R. F.L. Mau, S.-Z. Pang, M. Wang, C. Gonsalves, J. Watterson, D.M. Custer, and D. Gonsalves. 1998. Approaches for controlling tomato spotted wilt virus, p. 547-564. In: A. Hadidi, R.K. Khetarpal, and H. and Koganezawa (eds.). Plant virus disease control. APS Press, St. Paul, Minn.

Csizinszky, A.A., D.J. Schuster, and J.B. Kring. 1995. Color mulches influence yield and insect pest populations in tomatoes. J. Amer. Soc. Hort. Sci. 120:778-784.

Díaz-Pérez, J.C. and K.D. Batal. 2002. Colored plastic film mulches affect tomato growth and yield via changes in root-zone temperature. $\mathrm{J}$. Amer. Soc. Hort. Sci. 127:127-136.

Díez, M.J., F. Nuez, J. Costa, A. Lacasa, and M.S. Catalá. 1999. Tomato production under mesh reduces crop loss to tomato spotted wilt virus in some cultivars. HortScience 34:634-637.

Farías-Larios, J. and M. Orozco-Santos. 1997. Color polyethylene mulches increase fruit quality and yield in watermelon and reduce insect pest populations in dry tropics. Gartenbauwissenschaft 62:255-260.

Francki, R.I.B. and T. Hatta. 1981. Tomato spotted wilt virus, p. 491-512. In: E. Kurstak (ed.). Handbook of plant virus infections and comparative diagnosis. Elsevier/North-Holland Biomedical Press, Amsterdam.

Gitaitis, R.D., C.C. Dowler, and R.B. Chalfant. 1998. Epidemiology of tomato spotted wilt in pepper and tomato in southern Georgia. Plant Dis. 82:752-756.

Goodman, R.N., K. Zoltan, and K.R. Wood. 1986. The Biochemistry and Physiology of Plant Disease. Columbia, Univ. of Missouri Press.

Guillebeau, P. (ed.). 2001. Georgia pest control handbook. Commercial edition. Spec. Bul. 28, Coop. Ext. Serv., Univ. of Georgia.

Helyer, N. and P.J. Brobyn. 1992. Chemical control of western flower thrips (Frankliniella occidentalis Pergande). Ann. Appl. Biol. 121: 219-231.

Moriones, E., J. Aramburu, J. Riudavets, J. Arno, and A. Lavina. 1998. Effect of plant age at time of infection by tomato spotted wilt tospovirus on the yield of field-grown tomato. European J. Plant Pathol. 104:295-300.

Olson, S., J. Stavesky, T. Momol, and J. Funderburk. 2000. Reflective mulches and their effect on tomato yield and insect and disease management. Proc. Natl. Agr. Plastics Congr. 29:605-609.

Padgett, G.B., P.F. Bertrand, and J.D. Gay. Spotted wilt in Georgia's Crops. 1995. Coop. Ext. Serv., Univ. of Georgia and Ft. Valley State Univ. Bul. 1127.

Riley, D.G, and H.R. Pappu. 2000. Evaluation of tactics for management of thrips-vectored Tomato spotted wilt virus in tomato. Plant Dis. 84:847-852.

Roselló, S., M. J. Díez, A. Lacasa, C. Jordá, and F. Nuez. 1996. Viral diseases causing the greatest economic losses to the tomato crop. I. The tomato spotted wilt virus (TSWV) - A review. 
Scientia Horticulturae 67:117-150.

Salguero-Navas, V.E., V.E. Funderburk, J.E. Beshear, R.J. Olson, and T.P. Mack. 1991. Seasonal patterns of Frankliniella spp. (Thysanoptera: Thripidae) in tomato flowers. J. Econ. Entomol. 84:1818-1822.

SAS Institute Inc. SAS/C OnlineDoc ${ }^{\mathrm{TM}}$. Release 7.00. 2000. SAS Institute, Cary, N.C.

Schalk, J.M., C.S. Creighton, R.L. Fery, W.R. Sitterly, B.W. Davis, T.L. McFadden, and A. Day.
1979. Reflective film mulches influence insect control and yield in vegetables. J. Amer. Soc. Hort. Sci. 104:759-762.

Schalk, J. M. and M. L. Robbins. 1987. Reflective mulches influence plant survival, production, and insect control in fall tomatoes. HortScience 22:30-32.

Sherwood, J.L., T.L. German, J.W Moyer, D.E. Ul1man, and A.E. Whitfield. 2000. Tomato spotted wilt virus, p. 1030-1031. In: O.C. Maloy and
T.D. Murray (eds.). Encyclopedia of Virology. Wiley, New York.

Woodward, J. W. 2001. 2000 Georgia plant disease loss estimates. Univ. of Georgia, Coop. Ext. Serv., Publication Path 01-001, May 2001, $19 \mathrm{p}$

Zitter, T. A. 1997. Tomato spotted wilt, p. 40. In: J. B. Jones, J. P. Jones, R. E. Stall, and T. A. Zitter (eds.). Compendium of tomato diseases. APS Press, St. Paul, Minn. 